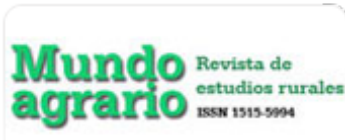

Mundo Agrario

ISSN: 1515-5994

mundoagrario@fahce.unlp.edu.ar

Universidad Nacional de La Plata

Argentina

\title{
Pastures, crops, and inequality: Questioning the inverse relationship between farm size and productivity in Colombia
}

\author{
Van Ausdal, Shawn \\ Pastures, crops, and inequality: Questioning the inverse relationship between farm size and productivity \\ in Colombia \\ Mundo Agrario, vol. 21, núm. 46, 2020 \\ Universidad Nacional de La Plata, Argentina \\ Disponible en: http://www.redalyc.org/articulo.oa?id=84562590009 \\ DOI: https://doi.org/10.24215/15155994e134 \\ Esta obra está bajo una Licencia Creative Commons Atribución-NoComercial-Compartirlgual 4.0 Internacional.
}


Dossier: Ganadería en el mundo americano: algunas reflexiones sobre tecnología, consumo e intercambio

\title{
Pastures, crops, and inequality: Questioning the inverse relationship between farm size and productivity in Colombia
}

\author{
Potreros, cultivos e desigualdad. Cuestionar la relación inversa entre el tamaño y la productividad de fincas en \\ Colombia
}

Shawn Van Ausdal

Universidad de los Andes, Colombia

sk.van20@uniandes.edu.co

DOI: https://doi.org/10.24215/15155994e134

Redalyc: http://www.redalyc.org/articulo.oa?id=84562590009

Recepción: 26 Agosto 2019

Aprobación: 20 Enero 2020

\begin{abstract}
:
The Colombian countryside has long been dominated by grass and inequality. Economic theory (i.e., the inverse relationship between farm size and productivity) holds that the monopolization of land by ranchers is irrational since farming is more productive than ranching and small farms often produce more per area than large ones. Traditional explanations for the predominance of grass and the country's agrarian structure focus on extra-economic coercion and the status associated with owning land and cattle. By contrast, this study explores the relative profitability of ranching and the limitations of peasant agriculture, which generated contrasting capacities to accumulate. It thus suggests that land markets, and the productive advantages of cattle, offer an alternative explanation.
\end{abstract}

KEYWORDs: Cattle ranching, Peasant agriculture, Agrarian history, Agricultural productivity, Animal studies, Colombia.

\section{RESUMEN:}

El campo colombiano ha estado dominado históricamente por potreros y marcado por una profunda desigualdad. Dado que la agricultura es más productiva que la ganadería y que las fincas pequeñas suelen producir más por área que las grandes, tanto el predominio del pasto como la estructura agraria parecerían ser irracionales en términos económicos. Las explicaciones tradicionales de esta situación se enfocan en la coerción extraeconómica y en la búsqueda del estatus por medio de la posesión de tierras. Este artículo enfatiza la rentabilidad relativa de la ganadería y las limitaciones de la agricultura campesina, que generaron capacidades muy disímiles de acumulación en estos dos sectores. Así, propone que el mercado de tierras y las ventajas productivas del ganado ofrecen una explicación alternativa al predominio de pasto y ganado.

Palabras clave: Ganadería, Agricultura campesina, Historia agraria, Productividad agrícola, Estudios de animales, Colombia.

\section{INTRODUCTION}

In 1949, Lauchlin Currie, sent to Colombia by the World Bank to formulate the country's first integrated development program, found "an unusual pattern" of land use: "the fertile, level valleys are used mostly for grazing, while the steep mountain slopes are cultivated” (IBRD, 1950, p. 62). Currie was not alone in noting the maldistribution of land use in Colombia. The geographer Raymond Crist (1952, p. 28) observed the same problem in the Cauca Valley in the 1940s; and two decades earlier, Alejandro López (1927, p. 54) complained that cattle, instead of farmers, occupied the best agricultural land in Antioquia. Such criticisms were partly rooted in a long-standing prejudice against pastoralism. In 1850, Manuel Ancízar observed that the predominance of stock raising on the Sabana de Bogotá represented "a step backwards, since grazing is the first step of civilization, which is not truly developed except by agriculture” (cited in Smith, 1969, p. 24). But to Currie and the others it also defied economic logic to keep the best farmland under grass since agriculture was more productive than ranching, an idea that dates back at least to the early nineteenth-century economist Johann Heinrich von Thünen (Griffen, 1973). While the owner of a large cattle estate may have earned a decent living, "such use of the land [was] not the best possible" (IBRD, 1950, p. 63). To drive home his 
point, Currie noted the irony of "cattle fatten[ing] on the plains while the people often have to struggle for a bare existence in the hills" (p. 63). The result of this "[in] efficient land use" was widespread poverty and low agricultural productivity, both of which stymied economic development (p. 63).

Currie's paradox was symptomatic of a larger puzzle. Cattle not only grazed on the best land in the country, they also monopolized the vast majority of its farmland (Dávila Tello, 1949). By 1960, with mechanized agriculture on the rise, grass still reigned supreme: over 16 million hectares compared to just 3.5 million hectares under crops (DANE, 1964, p. 25). ${ }^{1}$ For some, such expansive areas of forage underscored Colombia's “vocación ganadera" (Caja de Crédito Agrario, Industrial y Minero, 1966, p. 68; see also Flórez, 1926, p. 51). But this notion has tended to naturalize land uses and the agrarian structure that has sustained them. While Currie puzzled over the relative location of different rural activities, I am concerned with the spatial predominance of ranching. Outside of the Llanos, the vast savannas to the east of the Andes, the lopsided ratio of pasture-to-cropland rarely resulted from the ecological limits of farming; ranchers and peasants frequently vied for same land. By way of contrast, in the United States, where the average stocking rate was lower (i.e., ranching was more extensive), this same ratio was less than two-to-one (Wooten, 1953, p. 3). Given the high demand for foodstuffs (from a growing, malnourished population), and the resulting inflationary pressures, why was so much land left in grass? Similarly, given the pressing demand for land by much of the rural population, why didn't market forces help redistribute resources to more efficient uses?

There have been three broad ways - a political, a cultural, and an economic - of trying to explain this puzzle. According to the political perspective, ranchers extended their dominion largely through coercive means: Fals Borda's (1976) "Ley de tres pasos," for example. In turn, territorial monopolization solidified their leverage over a subjected peasantry. While this interpretation goes a long way to capture the historical dynamics of land use and concentration in Colombia, it oversimplifies a more complex story: the country's agrarian history cannot be reduced to relations of violence (or resistance). Likewise, the cultural viewpoint, which explains the agrarian structure as a function of the status of landholding, is equally unsatisfying. Eduardo Posada Carbó (1996) added an environmental dimension: ranching predominated in many areas because of the dual risks of flooding and insufficient rainfall. It is an important point, but the absence of large-scale investments in flood control and irrigation better explain the limits of plantation-style rather than peasant agriculture. My question, by contrast, focuses on the latter group: why did peasants end up with so little land compared to ranchers? ${ }^{2}$ This question is pertinent given the rich empirical tradition in economics which claims that output per area tends to be inversely proportional to farm size (Bardhan, 1973; Berry \& Cline, 1979; Cornia, 1985; Griffin, Khan, \& Ickowitz, 2002). The ability of farmers to sustain higher land prices through greater productivity is partly what allowed them to displace ranchers in the US from almost 90 million hectares between 1880 and 1950 (Wooten, 1953). In other words, where both agriculture and ranching are feasible, farmers should determine their relative spatial distribution. The situation in Colombia, in which ranchers expanded at the expense of peasants, is thus an economic anomaly. For this reason, efforts to explain the ubiquity of cattle estates invariably point to extra-economic forces that prevent factor markets (land, labor, and capital) from operating "normally."

While there are elements of truth to all these positions, they each start from the presumption that Colombia's continental sea of grass was an aberration. But what if this assumption is misguided? Could it be that the spatial predominance of ranching was partially underwritten by basic economic forces? In this article I play the devil's advocate in order to explore the hitherto unimaginable: that land markets facilitated the expansion of ranching and thus played a role in the development of Colombia's agrarian structure. My argument is that, at least between the late-nineteenth and mid-twentieth centuries, Colombian ranchers were often able to out-compete peasants on local land markets given the limitations of (semi-) subsistence agriculture. While Colombian ranching was not particularly profitable (measured in terms of net income per hectare), it could, contrary to expectations, hold its own against peasant farming. While peasants used land more intensely, their high costs of production (primarily labor), coupled with poor yields, lowered their 
net returns and limited their ability to outbid ranchers for land. In such conditions, land markets could help determine both land-use patterns and land-tenure structures.

Three words of caution. First, I say help determine because it would be foolhardy to state that the monopolization of landholding and the predominance of grass were entirely the result of smoothly functioning factor markets. Instead, what I am suggesting is that land markets, within the constrained conditions of the Colombian countryside, exercised more influence than is generally realized and should, therefore, be incorporated within a broader explanatory framework.

Second, this study is conceptual rather than historical. My objective is to compare the relative ability of peasants and ranchers to accumulate and acquire land via property markets. For this I rely primarily on studies of rural production undertaken by the Colombian government and development agencies in the 1960s and 1970s. I also refer to data going back to the early-twentieth century to question traditional narratives about ranching. Although the countryside was not static during these years, the transformations did not substantially alter the underlying dynamics I address. If anything, the slowly rising productivity of ranching, due to factors such as the spread of African grasses, tick-dipping vats, and mineralized salts, along with hybrid vigor from crossing creole and zebu cattle, favored ranchers (Van Ausdal, 2012). ${ }^{3}$

Third, the evidence I have been able to gather remains somewhat anecdotal. This is due, in large part, to the scarcity of detailed production data, especially of a comparative nature. Nonetheless, I feel that there is sufficient evidence, however circumstantial, to present this thesis in the hopes of provoking debate and, ultimately, working towards a better understanding of the profound inequalities that plague the Colombian (and Latin American) countryside.

\section{Traditional EXPLANATIONS}

Within the field of economics, the so-called Inverse Relation (IR) school has highlighted market imperfections and transaction costs to explain both the efficiencies of small-scale production and the persistence of unequal agrarian structures. ${ }^{4}$ This tradition presumes, based partly on empirical observations, that returns-to-scale in agriculture are constant (or even decreasing). In other words, there are no productivity advantages to enlarging farm size. This is especially true in the pre-modern, non-mechanized world of most developing-country agriculture prior to the 1950s. But even after farm machinery, highyielding seed varieties, synthetic fertilizer, and chemical pesticides became more readily available, many proponents have assumed that peasants could adopt these technologies as easily as large-scale farmers. Given constant returns-to-scale and perfectly functioning factor markets - in addition to similar conditions of production (i.e., land quality, crop choices, transportation costs, management ability, family lifecycles, etc.) - economic theory predicts that all farms should end up the same size. That this does not happen is due to market imperfections.

IR school proponents often identify differentiated factor markets - that small and large producers do not pay the same price for labor, land, and capital - as a key source of such imperfections. For example, the effective cost of labor is said to be greater on large farms than for family-run operations. The reason tends to be a combination of two processes. On the one hand, large farms have greater transaction costs hiring and especially supervising wage labor. By contrast, family farms, by tending to employ their own, reduce the burden of hiring outside workers and take advantage of built-in incentives to work efficiently. On the other hand, given the surplus labor that tends to exist in developing country agriculture (and the resulting disguised unemployment), peasants will often employ family labor even when it falls below the marginal value of production. In other words, the internalized cost of labor on peasant farms is often below wage rates in regional labor markets.

By contrast, the effective price of land tends to be lower for larger farms than for smaller ones. Transaction costs are part of the explanation: the bureaucratic expenses of subdividing and selling small properties are 
proportionally greater than for larger ones. Likewise, the cost of capital - accessing credit markets - is greater for smaller farms since processing costs do not decline proportionally and large borrowers often have greater political leverage. Many peasants are (or at least were) unable to access formal credit markets, forcing them to rely on village moneylenders and pay usurious rates of interest. On the other side of the equation, greater demand for small properties by land-hungry peasants meant that their price per area, assuming constant quality, was higher than that of larger properties. Peasants could afford higher land costs by growing laborintensive crops with greater value added, by avoiding (as much as possible) the transaction costs of hiring labor, and/or by "exploiting" themselves (or their family members) by working for less than going wage rates.

Because of these differentiated factor markets, peasants and landed elites, in the case of Colombia, had different forms of production. ${ }^{5}$ For landed elites, labor was relatively expensive while land and capital were comparatively cheaper. Given the incentive to economize on labor but use land more extensively, they tended to raise cattle or, once mechanized production was feasible (especially after World War II), substitute tractors for farm laborers (at least in land preparation). Peasants, on the other hand, had ample access to labor but were forced to economize on land and capital. As a result, small farmers were more productive in terms of area, but less productive in terms of labor (which they were willing - or forced - to apply in greater amounts). Since developing-country economies tend to be abundant in labor but short of capital and land (given unequal agrarian structures), proponents of the IR school have argued that labor-intensive agriculture ensured a socially more efficient use of national resources. Given the existing market imperfections, which prevented the factors of production from being redistributed to more efficient uses, they have also tended to advocate for government-led land reform.

The second explanation is cultural, although it often includes both economic and political elements as well. The central proposition is that the economic function of land and cattle was secondary to their prestige value (Denevan, 1982, p. 25; Shane, 1986, p. 9; Tucker, 2000, p. 330). The geographer James Parsons, for example, observed that "raising cattle is a prestigious activity in Latin America, it's part of the culture. It is not necessarily sensible from the economic point of view..." (cited in Reyes, 1986, p. 210; see also Crist, 1952, p. 41). Similarly, to explain why more than 65 percent of the fertile Cauca Valley should be "devoted to extensive cattle raising that generally yields an apparent return which is much less than the cash rental value of the land," agricultural economist, G. I. Trant (1958, p. 124), noted that "In the two years that [he] spent in the Cauca Valley he was unable to get a complete explanation. Part of the answer appears to stem from the social prestige and insurance advantages of land ownership in Colombia." Given the relative ease of ranching, many scholars of Latin America have also stated that the primary function of cattle has been the maintenance of territorial control. ${ }^{6}$ Here the status of landownership merges with indirect economic rationales, such as asset diversification, a hedge against inflation, and the speculative value of landholding. It is also tied to questions of political power, which brings us to the third line of reasoning.

A political economy perspective is probably the most widespread explanation within the social sciences. It stands apart from the IR school in two respects. First, it asks about origins whereas the IR school tends to take the agrarian structure as given, asking instead why market forces do not alter it. Second, it explains the agrarian structure (and concomitant land uses) in terms of social relations rather than market imperfections. Central to this perspective is the leverage over peasant communities that the monopolization of landownership provides. Proponents stress how artificial land scarcity forged a readily available and pliant labor force. With more land than they could effectively use, landed elites offered small plots to grateful peasants in exchange for rental payments (sometimes on a share basis) or labor services. The degree of desperation, itself a function of land monopolization, could skew the terms decidedly in favor of landlords. Tenant farmers also formed an on-call pool of labor, which lowered the costs of hiring; and the threat of expulsion into a land-scarce world gave them an incentive to work diligently (Richards, 1979). Landed power also enabled rural elites to exploit peasants in multiple spheres: for instance, by controlling access to markets, monopolizing the sale of consumer goods, manipulating debtor rolls, and taking advantage of unpaid family 
(or state-sanctioned) labor (see Dyer, 2004; Palacios, 2011). Land, therefore, supported a form of economic power that operated beyond the realm of pure market forces. As Griffin, Khan, and Ickowitz (2002) argue, the economic position of rural elites rested on their monopolization of landholding, which discouraged them from subdividing their properties and, in turn, prevented land markets from operating effectively.

According to this perspective, landownership also endowed rural elites with political power. Control over captive communities - whether in the form of cannon fodder during the nineteenth century or voters (and partisan bullies) in the twentieth century - enabled rural elites to position themselves within larger political networks. A "lord-vassal pattern," stretching from the local level to the highest echelons, is how political scientists often imagine the origins of clientelism in Colombia (Martz, 1997, p. 18; see also Archer, 1990; Henderson, 1985). In turn, political power exercised through the state (or sometimes in its absence) reinforced the power of rural elites at the local level. They could count on the judiciary and police to back them in land and labor disputes, or to turn a blind eye to the economic prerogatives they claimed; the state liberally handed out titles to large extensions of public lands, replicating the colonial land tenure structure on the agrarian frontier; and it did little to thwart the de facto appropriation by elites of non-adjudicated public lands and peasant property claims. The most frequent depiction of this process is of a ranching juggernaut progressively extending its "iron grip" over the countryside (Yepes 2001, p. 151). Although such views often date to the 1970s and 1980s, they have been remarkably durable. For example, the Grupo de Memoria Histórica (2010, p. 64) recently resurrected Orlando Fals Borda's “ley de tres pasos" to highlight the panoply of "tricks, pressures, exactions, deceits, and deaths" that pervaded the unrelenting process of enclosure in the Caribbean region as it became the center of ranching in Colombia.

While the IR perspective uses market imperfections to explain the predominance of grass and landed elites, proponents of a broadly defined political economy point to the exercise of political power. In both cases, however, market forces have little influence: in the former they fail to operate while extra-economic forces predominate in the latter.

\section{QUESTIONING TRADITIONAL EXPLANATIONS}

Do such accounts adequately account for patterns of land use and the extent of landed-elite control over the countryside? While there are elements of truth to each of these perspectives - which is why they have persisted, albeit sometimes in parallel spheres - problems arise when one closely examines the historical record.

Land ownership and cattle were prestigious because they were both visible signs of wealth and power. Landed status was relative, however. In the early-twentieth century, a moderate-sized property on the Sabana de Bogotá could easily trump an extensive cattle estate amidst lowland forests where, on top of being difficult to reach, living conditions were likely primitive and the chances of contracting malaria were high. Additionally, developing a cattle estate on the agrarian frontier was laborious and costly. While the prestige and relatively easy income derived from an inherited hacienda in the Cauca Valley may have compensated for the lost opportunity cost of more productive land uses even into the 1960s (see Grunig, 1968), out on the agrarian frontier - where much of the ranching sector had been expanding since the mid-nineteenth century - such nonchalance could quickly lead to actual losses rather than just lost opportunities. Marco A. Salazar, who oversaw the development of cattle estates along the lower Cauca River in the early-twentieth century for Pedro Nel Ospina \& Company, was acutely aware of this dilemma. "Every year we spend a fortune and the interest [we pay] is killing us," he warned. ${ }^{7}$ But Ospina's order to dramatically reduce expenses was equally "impossible ... since it would amount to renouncing the coronation of so much work and resign ourselves to lose an enormous sum of money and effort that these new works represent." ${ }^{8}$ As I have argued elsewhere (Van Ausdal, 2009a), such risks suggest that the business of ranching need to be taken more seriously and, as a corollary, that the status of ranching alone is an insufficient explanation. 
In similar fashion, the costs of developing a cattle estate (or buying an established one) were too high to presume that the political power associated with territorial control was the principal objective. If the exercise of power was motivated partly for monetary gain, the initial investment could not produce losses greater than the subsequent extra-economic earnings. While a rancher might forgo the opportunity to make more lucrative investments, the cattle operation needed to be economically viable. Territorial control and the political power it engendered could increase leverage over peasant communities, thereby lowering labor costs, encouraging land-for-pasture exchanges, ${ }^{9}$ and facilitating the appropriation of communal resources and peasant land claims, among other practices. But for the cattle estates whose archives I have examined, these extra-economic gains were not central to their profitability (Van Ausdal, 2009b; see also Ocampo 2007). Additionally, control over land mattered more to ranchers than control over people. While the development of new pastures required considerable labor, ranchers typically wanted to reduce their resident tenants, and overall labor costs, as quickly as possible. Ranching's limited labor demands could itself be construed as another form of control, but out on the agrarian frontier, at least, the actual sway that ranchers held over the local labor force was more limited than often imagined. Since this is where much of the ranching sector was expanding, it was also a region with some of the highest labor demands. But because ranchers had not monopolized all the land, it was also where peasants had more autonomy and wages were relatively high, at least before the mid-twentieth century. From their correspondence, we see the frustration that ranchers from such regions experienced trying to hire help and limit wages paid in advance and the accumulation of debts (Van Ausdal 2009a; Ocampo 1988). In other words, macro-level assumptions about landed power can break down as the scale of analysis narrows.

Ranchers did take advantage of their power to appropriate land, often from peasant settlers (colonos). The government archives in Bogotá are full of complaints by peasants about such land grabs. Social scientists, along with popular memory, have forged a national narrative about the unrelenting and often violent process of enclosure through much of the Colombian countryside (Reyes, 1978; Taussig, 1978; Fals Borda, 2002; Gaitán, 1984; Kalmanovitz, 1989; Molano, 1994; Grupo de Memoria Histórico, 2010). There is much truth to this story, which is why it had taken hold so firmly. To give one example, residents from Margarita (Bolívar) forewarned the Minister of Public Works in the early-twentieth century: "If the law will not protect our property rights, if because we are poor and weak and cannot defend ourselves, if honorable labor is not to be respected, we know which roads we must follow: either the path of crime or that of migration" (cited in LeGrand, 1986, p. 65).

But this narrative is a one-sided story that misses parallel processes by which land concentration also occurred. For example, Michael Taussig $(1974$, p. 70; 1978) reduces the expansion of capitalist farming in the southern Cauca Valley to a history of forced appropriation despite the fact that land sales were "customary" within the peasant community. ${ }^{10}$ Similarly, Catherine LeGrand's (1986) authoritative study of the settlement of public lands (baldios) emphasizes coercion and conflict partly because it is the records of such land disputes that reside in government archives. By contrast, less contentious land sales did not generate the same paper trails. LeGrand recognizes that selling land cleared of forest to ranchers was one way that peasant colonos could capitalize their labor in frontier regions. But while she argues that such sales were inconsequential, I suggest they were significant enough to warrant more attention (see Van Ausdal, 2009b, pp. 134-141). Prior to the mid-twentieth century, notary archives offer a glimpse into informal land markets as new property owners decided to register a purchase (usually of possessory or improvement rights since most peasants did not have land titles). Brief histories of the property, used to back ownership claims, also hint at more active land markets than are often suspected. In Montería (then in the Department of Bolívar), two-thirds of rural land sales registered in the notary between 1908 and 1950 (out of a sample of 560) were for properties smaller than 60 hectares. By 1960 almost 90 percent of rural land sales in nearby Cereté fell under this threshold (Havens, Montero, \& Romieux, 1965, p. 75). Since then, stories about the expansion of ranching into humid tropical forests, both in Colombia and elsewhere in Latin America, confirm the pattern 
of ranchers buying up - rather than simply expropriating - peasant farms on the agrarian frontier (Molano, 1996, pp. 45-46; Balcázar, 1994; Humphries, 1998).

The question remains, however: how often were such sales underwritten by coercion? Undoubtedly many were, as numerous examples of forced land sales clearly show (Taussig, 1978; Oquist, 1980; Reyes \& Duica, 2009; Grajales 2011). Nonetheless, coercion is sometimes more gray than black and white. In 1925, a commission led by José Eustacio Rivera, famed author of La Vorágine, examined allegations that, in the formation of Hacienda Corinto, near Ayapel (Bolívar), Pedro Nel Ospina \& Company had pressured colonos to sell their farms. Out of some 15 peasants and ranchers who sold their possessory rights to Corinto, about one-third complained that the price they received was below "market value." But evidence of coercive tactics was not straightforward despite Rivera's antagonism toward the president. Pedro Noriega, a farmer from Ayapel, mentioned that "some ... pioneer farmers (colonos cultivadores) sold for less [than their land was worth] out of fear that the House of Corinto would make good on its promise to apply for title" to these public lands. ${ }^{11}$ By contrast, Manuel Dolores Gil told Rafael Vejarano, a rancher from San Benito Abad, that he had "sold well ... because they stood up and said that if [Corinto] did not give them what they were asking for, they wouldn't sell, and in the end he got what he asked for...." 12 Similarly, Tomás de Amores, a farmer from San Benito Abad, denied that he or any others sold against their will. And Martín Angulo, also included in the list of victims, stated that "the majority of those colonos sold their farms to Corinto ... by their own will, each one satisfactorily receiving their value except for the speaker [Angulo], who sold his a little cheaply, because they filled him with fear that they would circle his farms with fences and leave him without any room to expand...." 13

While it does not appear that Hacienda Corinto openly forced colonos to sell their farms and pastures, it certainly had more negotiating power, in part due to the dread of becoming engulfed within a huge, powerful estate (cf. Taussig, 1974, p. 72). The conflict in this case thus centered on the question of price rather than just expulsion (despojo). Privately, Bernardo Ospina, who managed Pedro Nel Ospina's properties in this region, admitted that he could buy these properties "at a very low price." ${ }^{14}$ But he also complained that "these properties are not very productive": the large ones were in "terrible condition" and would require "considerable expense until they can be fixed up and are in a state to produce something"; and the rest were "overgrown fields (rastrojos) and some grass but in small quantities and are unusable because they are so far from headquarters." ${ }^{15}$ In other words, different valuations of the same property also colored disputes. What I want to suggest, by way of this account, is that informal property markets, for all their deficiencies and asymetries, were an imprortant mechanism by which ranchers swallowed up peasant farms. While coercion could permeate such sales, this was not the only dynamic. ${ }^{16}$

But how could ranchers take advantage of property markets to buy up peasant farms if raising cattle was less productive than farming? Here my suggestion is that, compared to (semi-) subsistence agriculture, ranching was not necessarily less profitable. Underlying much of the IR literature is a normative judgment of what land use and distribution should look like rather than an effort to understand their origins. Proponents focus, therefore, on the social inefficiencies of large-scale farming and stock raising rather than pay attention to the private gains from these activities. Peasants used scarce resources more efficiently, but ranchers may have been able to earn enough per hectare by raising cattle to compete with small-scale farming in local land markets. While it is true that bureaucratic hurdles put a damper on formal land markets, they were less of a problem for informal sales. Alternatively, if subsistence agriculture was more profitable than ranching, why didn't landowners simply rent their properties to peasants? That they were more interested in raising cattle than being landlords - even before the threat of land reform discouraged tenant farming - suggests that the relative profitability of cattle may have been better than often imagined. 


\section{Grass vS. SUBSISTENCE FARMING}

Studies that compare the production and costs of ranching and subsistence agriculture in Colombia are hard to find. In fact, most productivity studies, which gathered force in the 1960s, were more interested at showing what could be achieved through agricultural modernization than what was actually done. Detailed studies of peasant agriculture are scare, therefore; and farm-level analyses of ranching productivity are even rarer. As a result, evidence providing insight into the comparative profitability of ranching and peasant agriculture is limited and of scattered origin. For now my claims must remain suggestive.

Let me start with peasant agriculture. Most of my focus will be on staple crops, such as corn, which used the bulk of small-farm resources. I also focus primarily on the lowlands where the competition between ranchers and peasants was more acute. The central point I want to make is that (semi-) subsistence agriculture, at least through the mid-twentieth century, was labor intensive and not very productive. Efforts to modernize the Colombian countryside often depicted peasant farming as "primitive" due to its reliance on simple tools, human power, traditional seeds, and limited inputs (CIDA, 1966, p. 163). Since then some scholars have tried to rehabilitate our understanding of peasant agriculture, underlining its own efficiencies, rich knowledge base, environmental stewardship, resilience, etc. (Schultz, 1964; Altieri \& Toledo, 2011). But even after dropping the former disdain, one is still left with a form of cultivation that produced little despite enormous efforts. For example, to grow one hectare of rice in the Caribbean municipality of Tolú in 1963 required 82 days of labor on one farm: some 46 days to prepare the land, 11 days to plant, and 20 days to weed (See Table 1). In addition, the farmer interviewed paid 480 pesos, or the equivalent of about 48 days of labor, to have his rice crop harvested (Wood, 1966, pp. 126-127). This amount of labor may have been on the high side since older farmers from Tolima recalled that pre-mechanized rice production (before the 1940s) required about 70 man-days per hectare (Thirsk, 1972, p. 292). Similarly, two small farmers in Córdoba in the early 1970s used 64 and 67 days of labor per hectare to grow a combination of corn and rice (Thirsk, 1972, p. 292). In neighboring Panama, the economic anthropologist Stephen Gudeman (1978, p. 79) noted that peasants in the community he studied in the mid-1960s expended 98 days of labor to grow one hectare of rice (intercropped with corn and some beans) and a second crop of corn. Per-hectare labor estimates for traditional methods of corn production around Colombia are similar, ranging from 52 to 73 days in the 1950s and 60s (Table 2; see also ECLA 1957, p. 200). Likewise, researchers from the Centro Internacional de Agricultura Tropical, or CIAT (1975) found that peasants in the Cauca Valley and Quindío in the early 1970s expended 114 days of labor per hectare to grow yucca, and about 150 days of labor when they intercropped yucca with corn or beans. 
TABLE 1

Labor and expenses of a peasant a rice farmer in Tolú (Bolívar), 1963

\begin{tabular}{|ll|l|}
\hline Labor & Days & Expenditures \\
\hline Make a path in the forest (fallowed field) & 1 & $\begin{array}{l}\text { Harvest the rice (by contract; wages averaged \$10 } \\
\text { per day) }\end{array}$ \\
pesos
\end{tabular}

Source: Wood, 1966, pp. 126-127.

TABLE 2

Labor-days per hectare of basic grains on peasant farms

\begin{tabular}{|lllll|}
\hline Crop & Days of labor & Location & Year & Source \\
\hline Rice & 70 & Tolima & 1930 & Thirsk, 1972 \\
\hline Rice & 82 & Tolú (Córdoba) & 1963 & Wood, 1966 \\
\hline Rice & $64-67$ & Córdoba & 1970 & Thirsk, 1972 \\
\hline Rice + + corn) & 98 & Panama & 1965 & Gudeman, 1978 \\
\hline Corn & $52-58$ & Córdoba & 1954 & Caja Agraria, 1955 \\
\hline Corn & $65-73$ & Rionegro (Antioquia) & 1963 & Guerra, 1966 \\
\hline Corn & 65 & Colombia & 1971 & Cespedes, 1979 \\
\hline
\end{tabular}

The labor requirements mentioned above are only for a single (or intermixed) crop, however; the total labor expended per hectare for a peasant farm could be significantly higher. According to data provided by Thirsk (1972, p. 26), small farms in Boyacá and Caldas used 193 and 102 days of labor per hectare respectively. Londoño (1975, p. 101) found that peasant farms with less than 4 hectares expended a total of 154 days of labor per hectare. (This dropped by half in farms with 4 to 10 hectares, illustrating the inverse relationship.) Researchers from the Comité Interamericano de Desarrollo Agrícola or CIDA (1966, p. 512), an effort by the Organization of American States to study agricultural development and land reform, described the case of a peasant family in the hills of Huila that worked a total of 1,500 days (out of a total possible of 1,750 days, given the large family) on their nine-hectare farm. But since six hectares were in forest and half-a-hectare was in unused pasture, the labor expenditure per hectare of actually cultivated land - one in coffee, half in plantains, and one in yucca and peas - was 600 days. These estimates are crude and subject to any number of errors. But the main point remains: peasant agriculture was labor intensive.

Despite all this work, yields were often low (Table 3; see also ELCA, 1957, p. 170). Through the 1950s, one hectare yielded on average a little more than 1,000 kilograms of corn. Contrary to the expectation of the IR literature, yields for small farmers were often 15-25 percent less (see Atkins, 1970, p. 20; ELCA, 1957, p. 172). For example, researchers in the Cauca Valley found that corn yields on peasant farms under 19 hectares varied between 503 and 826 kilos per hectare (CVC, 1962, p. 50). Similarly, Haney (1971, p. 89) reported that peasants in Fómeque (in the Eastern highlands) averaged only 679 kilos of corn per hectare. In Panama, Gudeman (1978) found that peasant farmers produced 960 to 1,600 kilograms of rice in one hectare 
and, subsequently, 400 to 570 kilos of corn (in the less productive, secondary harvest). By 1971, average yields on peasant corn plots had risen somewhat to 1,050 kilos per hectare (Cespedes, 1979). In the early 1970s, CIAT (1975, p. 8) found that the yields of peasant-grown yucca, on average, varied between 1,100 kilograms (intercropped with corn) to 1,300 kilos per hectare (alone or intercropped with beans). While some peasants were able to achieve relatively high levels of output per area, in general they lagged behind what large-scale farmers were starting to achieve with modern inputs and management. For example, yields of corn on large, mechanized farms in the Cauca Valley were about double those of small farms using traditional methods (CVC, 1962, p. 50; see also Atkins, 1970, pp. 24-26; Taussig, 1974). But more significant than the comparison with mechanized farming was simply the fact that yields for (semi-) subsistence agriculture were particularly low given the amount of labor expended. In the 1950s, a Colombian peasant could easily take 50 days, or 500 hours, to grow 1,000 kilos of corn, which is just two kilograms of corn per hour. By way of comparison, in 1940 the average US farmer produced 1,000 kilograms of corn in 40 hours, or 25 kilograms per hour (US Department of Commerce, 1975, p. 500, Series K 445-485). This comparison might not be fair, however, since these farmers used machinery and, increasingly, hybrid seeds. But even in the mid-nineteenth century, the average US farmer produced 10 kilos of corn per hour of labor. The combination of high labor expenditure and low yields meant that peasant agriculture was not very productive.

TABLE 3

Yields per hectare of peasant agriculture

\begin{tabular}{|lllll|}
\hline Crop & Yield $\mathbf{( k g} / \mathbf{h a})$ & Location & Year & Source \\
\hline Corn & 1,000 & Colombia & 1950 s & Atkins, 1970 \\
\hline Corn & $503-826$ & Valle del Cauca & 1960 & CVC, 1962 \\
\hline Corn & 679 & Fómeque & 1970 & Haney, 1971 \\
\hline Rice & $960-1,600$ & Panama & 1965 & Gudeman, 1978 \\
\hline Corn & $400-570$ & Panama & 1965 & Gudeman, 1978 \\
\hline Yucca & $1,100-1,300$ & Caldas & 1973 & CIAT, 1975 \\
\hline
\end{tabular}

So how does ranching compare? For one, the yields per hectare were even smaller. While comparisons of cattle and crop productivity present certain difficulties, a simple way to begin is to roughly calculate the annual weight gain of a steer. In mid twentieth-century Colombia, the average slaughter age and weight of steer was about 4.5 years and 450 kilos (Van Ausdal, 2012; Dávila Tello 1949, p. 43). This gives a very crude annual growth rate of about 100 kilos per hectare, given the average carrying capacity of one head per hectare. Converting beef and corn yields to calories highlights the productivity differences: assuming a carcass yield of 50 percent, and 2,500 calories per kilo of beef (with 15 percent fat) and 3,500 calories per kilo of corn, then the difference in output per hectare is a factor of 28 . Sometimes ranchers fared better. For example, in the mid-1960s a study by the Instituto Latinoamericano de Mercadeo Agrícola (ILMA) of nine cattle ranches in the Honda-La Dorada region of the Magdalena River Valley found the average stocking rate to be about two head per hectare. These ranches bought cattle at 18 to 20 months and sold them two years later when they weighed about 475 kilos. Assuming the feeder cattle they purchased weighed 200 kilos each, this gives an annual weight gain of perhaps 275 kilos per hectare. Still, both gross income and calories per hectare were far lower for pasture than for crops. The productivity of Colombian ranching was also low by international (i.e., temperate) standards (United Nations, 1962; Van Ausdal, 2016).

What helped compensate for poor yields were relatively low production costs, especially in terms of labor (Table 4). In 1968, cattle ranches in the Cauca Valley and Meta reported annual labor requirements of 19 days and 1 day per hectare respectively (Thirsk, 1972, p. 26). On a cattle latifundio in Antioquia, the total labor expenditure per hectare was only 6.6 days (CIDA, 1966, p. 450). Ranches in the Honda-La Dorada region studied by ILMA (1966, p. 60) used, on average, only six days of labor per hectare to maintain pastures and fences and only one cowboy to watch over 250 head of cattle. ${ }^{17}$ Labor demands were not always so low, 
however. Developing a new ranch in a forested region (where ranching was expanding) initially required considerable more. In the early 1920s, for instance, it took about 20 days of labor to clear one hectare of forest; then the land had to be planted in pasture (by hand with stolons or runners for pará grass) followed by two "expensive" rounds of weeding before it was well established. ${ }^{18}$ Afterwards, it still needed to be weeded periodically, but the initial expenses dropped and the development costs could be amortized over the 10- to 15-year lifespan of the pasture (ECLA, 1957, p. 411; Randell, 1953). Thus the low labor demands of ranching were not solely because of its extensive nature and economies of scale. The comparatively low labor demands of land preparation (spread out over a decade or more) and harvesting (which the cattle did themselves) were also significant.

Table 4. Labor and income per hectare on cattle ranches

TABLE 4

Labor and income per hectare on cattle ranches

\begin{tabular}{|lllll|}
\hline Days & Income (pesos) & Location & Year & Source \\
\hline-- & $\$ 350$ & Tolú (Córdoba) & 1963 & Wood, 1966 \\
\hline 6.6 & $\$ 458$ & Honda-La Dorada & 1965 & CIDA, 1966 \\
\hline 6 & $\$ 411$ & Antioquia & 1965 & CIDA, 1966 \\
\hline-- & $\$ 600$ & Magdalena & 1965 & CIDA, 1966 \\
\hline-- & $\$ 200-500$ & Tolima & 1965 & CIDA, 1966 \\
\hline 1 & -- & Meta & 1968 & Thirsk, 1972 \\
\hline 19 & -- & Valle del Cauca & 1968 & Thirsk, 1972 \\
\hline
\end{tabular}

But my main question is how peasant agriculture and ranching compared in terms of net income per hectare. The former produced more with greater effort while the latter produced less with little labor. But which activity was more profitable? Again, figures are hard to come by and vary a good deal. The CIDA (1966, p. 175) study estimated that the net income for ranching operations on the plains of Huila varied between $\$ 200$ and $\$ 500$ pesos per hectare. From interviews with two ranchers from Tolú (Bolívar), Wood (1966, pp. 31-33, 123-125) found that one had an income of $\$ 127$ pesos per hectare while the second estimated his net return to be about $\$ 350$ pesos per hectare. The former, however, was in the middle of modernizing his ranching operations, which considerably increased his costs. On the basis of rancher interviews, ILMA researchers estimated the net income per hectare of beef production in the Honda-La Dorada region to be $\$ 458$ pesos. Even the poorly managed cattle latifundio that CIDA $(1966,451)$ researchers analyzed in Antioquia obtained the net income $\$ 411$ pesos per hectare. And in a case from Magdalena, they estimated ranch income to be almost $\$ 600$ pesos per hectare (CIDA, 1966, p. 455). Despite this limited sample size, we might presume that a rancher in the early 1960s would expect a net income of about $\$ 400$ pesos per hectare (see Table 4$).{ }^{19}$

How does this compare to peasant farms? Here the estimates are even scarcer and more varied. In the hills of Tolima, CIDA (1966, p. 175) researchers estimated that the income per hectare of peasant farms varied between $\$ 300$ and $\$ 700$ per hectare. In the early 1960 s, government researchers calculated that the net income from corn production averaged $\$ 440$ per hectare (Guerra 1966, p. 71 ). ${ }^{20}$ Jumping to the early 1970s, a number of farm-level productivity studies undertaken by USAID also show roughly similar net incomes per hectare between crops and cattle (see Table 5). And Londoño (1975, p. 123) estimated the opportunity cost of cropland in García Rovira (Santander) to be $\$ 546$ per hectare while that of pastureland was $\$ 656$. Even if the net income per hectare were somewhat higher on peasant farms, it does not seem to have been substantially greater than what ranchers might have earned (see Table 6). This could be one of the reasons why rural elites, particularly before tractors and modern inputs became more readily available, preferred cattle to crops or even tenant farmers. ${ }^{21}$ 
TABLE 5

Income per hectare Colombian pesos circa 1970

\begin{tabular}{|l|llllll|}
\hline \multicolumn{7}{|c|}{ Location } \\
\hline Activity & Meta & Caquetá & Boyacá & Santander & Tolima & Córdoba \\
\hline Cattle breeding & 174 & 158 & 764 & 106 & 263 & -- \\
\hline Yucca & 339 & -- & -- & -- & -- & -- \\
\hline Corn & 250 & 69 & 749 & -- & -- & 291 \\
\hline Rice & 424 & 76 & -- & 77 & -- & -- \\
\hline Plantain & 320 & 255 & -- & 80 & -- & -- \\
\hline Potatoes & -- & -- & 1.163 & -- & -- & -- \\
\hline Sugarcane & -- & 151 & -- & -- & -- & -- \\
\hline
\end{tabular}

Source: Baines and Steen, 1971.

TABLE 6

Ranching vs agriculture Income per hectare Colombian pesos

\begin{tabular}{|lllll|}
\hline Activity & Income & Location & Year & Source \\
\hline Ranching & $\$ 458$ & Honda-La Dorada & 1965 & CIDA, 1966 \\
\hline Ranching & $\$ 411$ & Antioquia & 1965 & CIDA, 1966 \\
\hline Ranching & $\$ 600$ & Magdalena & 1965 & CIDA, 1966 \\
\hline Ranching & $\$ 200-500$ & Tolima & 1965 & CIDA, 1966 \\
\hline Ranching & $\$ 350$ & Tolú (Córdoba) & 1963 & Wood, 1966 \\
\hline Ranching & $\$ 656$ & García Rovira & 1973 & Londoño, 1975 \\
\hline Agriculture & $\$ 546$ & García Rovira & 1973 & Londoño, 1975 \\
\hline Agriculture & $\$ 300-700$ & Tolima & 1965 & CIDA, 1966 \\
\hline Corn & $\$ 440$ & Various departments & 1963 & Guerra, 1966 \\
\hline
\end{tabular}

Of course, it is difficult to calculate profit rates for small-scale agriculture because many peasants thought more in terms of survival or reproduction. One result of this perspective was the tendency for peasants pay themselves, or their family members, less than they might earn working off the farm (if they could find employment). For example, the peasant farm from Huila analyzed by CIDA (1966, p. 511) produced the equivalent of 900 pesos per hectare, most of which came from growing yucca. Calculated only on the basis of the area actually cultivated, however, yields a gross income of $\$ 3,240$ per hectare. Since this peasant family expended 600 days of labor per hectare, if they had hired labor instead of doing it themselves, the farm would have produced a huge loss (at wages of $\$ 10$ pesos per day). Valuing their labor at half the going wage rates, the farm probably "broke even." 22 In other words, how labor expenses are calculated has an important impact on comparisons between family-operated farms and larger ones, such as ranches, that depended on wage labor.

But if the question is which activity could outbid the other in local land markets, then the wage differentials might not be so important. The real question comes down to which activity accumulated more and could translate these earnings into land purchases. Here the labor demands of peasant agriculture placed an upper limit on what each peasant could grow and thus accumulate. ${ }^{23}$ For example, in the Panama village that Gudeman (1978) studied, each farmer could farm about 1.5 hectares per year without paying for outside help. After subtracting subsistence needs, the marketable leftovers brought in little income. Much of this income then went to purchase goods and services the peasants were unable to produce themselves. As a result, it often took peasants a long time to accumulate the capital necessary to buy land. For instance, the CIDA's (1966, p. 512) case study of a peasant from Huila noted that it took him about twenty years to save enough money to buy his first farm.

By contrast, ranching not only appears fairly competitive with peasant agriculture, but ranchers were able to accumulate extensively (and could tap less expensive credit). As a result, they had an easier time buying peasant farms when they became available on local land markets. The potential movement in the opposite 
direction was harder because peasant agriculture does not appear to have been significantly more productive (in terms of income per hectare), and because transaction costs discouraged subdividing large properties. This is what the American Colombian Corporation realized when it contemplated selling off part of its property, the Tierras de Loba (near Mompós, Bolívar), to peasant "squatters" in the late 1950s: the legal costs were greater than the value of the potential land sales. ${ }^{24}$ Renting could have been an alternative way to promote more efficient use of resources - if there were no political risks of losing one's land to tenants - but even then the transaction costs of renting to many peasants rather than one or a few large farmers may have provided a disincentive.

Various other factors reinforced the comparative advantage of ranching. Out on the agrarian frontier, the difficulty of transporting crops to market favored cattle. Livestock also tended to be less risky than agriculture: they could walk away from climatic problems and, because of their slow rates of reproduction, ranchers suffered less from the wild price swings that often plagued farmers. Cattle also had the advantage of being a liquid asset, which allowed ranchers to sell off herds rather than land during difficult times. Especially before the mid-twentieth century, when investment opportunities were limited, cattle and ranching represented a relatively safe form of asset diversification. The fact that ranching was easier to manage from a distance than agriculture was an important consideration for elites who often earned a good deal of their income from professional occupations. Finally, converting undeveloped land to pasture was itself a fairly safe investment if the production costs could be kept under control. And landed properties tended to retain their value in inflationary economies.

The economic advantages of cattle started to diminish with the introduction of modern agricultural practices, however. By substantially increasing the potential earnings per hectare, mechanized farming raised the opportunity cost of raising cattle. Beginning in the 1930s in a few places, and expanding during the 1950 s, this new style of farming finally began to displace extensive ranching from the fertile valley floors (Zamosc, 1986; Hirschman 1963, 118). New capitalist farmers took the lead, renting land from older ranching families. The process was slow, however, because some latifundista families earned enough from their extensive operations to postpone changes (Crist, 1952, p. 35); and because the prospect of losing money, given the high expenses, was real (Grunig, 1968). But these changes show that when the income differential was sufficiently great, land use started to shift from cattle to crops. That this same redistribution of resources did not occur through pressure from peasant agriculture suggests that, in part, the differential was not sufficiently large. While it might seem that land markets had scant influence before the mid-twentieth century, my argument is actually the opposite: they favored the accumulation of land in the hands of ranchers rather than peasants.

Land markets were not the only factor in the formation of a lopsided land tenure structure and the ubiquity of grass. Dispossession was a prominent feature of rancher-peasant relations, as many have argued (Reyes, 1978; Fals Borda, 2002; Grupo de Memoria Histórica, 2010). Also central was the state's profligate reliance on public-land bonds, which, heavily discounted, favored the creation of large estates on the agrarian frontier (LeGrand, 1986). Even more significant than the privatization of public lands was the de facto concentration made possible by the relative absence of the state on the agrarian frontier and laws that permitted the establishment of possessory rights. While the state expected settlers to seek title to their land claims, many did not do so. For peasants, the legal costs were often too great (LeGrand, 1986). But many ranchers and rural elites did not bother to seek formal title to their claims either. In some cases, maintaining possessory rights may have allowed them to bypass size restrictions or avoid compensating peasants previously settled inside their claims; it may have also just been a question of avoiding the bureaucratic costs of formalizing their property. Their willingness to forgo formal title attests to the widespread acceptance of "informal" or possessory rights. As mentioned above, LeGrand (1986) recognized the existence of such property markets, but dismissed them as relatively unimportant. Others, such as Orlando Fals Borda (1976), argued that they offered a veneer of legitimacy to the tricks and coercion that pervaded rancher-peasant 
relations: improvement rights were, in the end, often purchased, but the terms were imposed rather than negotiated. Such accounts are significant, but they focus, I suggest, on one side of a larger, more complex process. These same property markets were not only a means to legitimize dispossession, they could also operate, however imperfectly, according to basic economic forces. That ranchers dispossessed peasants because they wanted lands that peasants did not want to sell or because such land theft amounted to a form of primitive accumulation - is not disputed. What I question is whether this was the only (or principal) dynamic behind the formation of the land tenure structure of mid twentieth-century Colombia. My argument is that parallel to such processes, there was another, less conspicuous force that fomented the concentration of land ownership and the predominance of cattle: the relative profitability of ranching versus (semi-) subsistence agriculture.

\section{Conclusions}

Why was the Colombian countryside covered in grass and monopolized by relatively few people by the midtwentieth century? While the reasons behind the predominance of ranching and ranchers are multifaceted, land markets have been a missing element in most historical accounts. Raising cattle was not always the most profitable endeavor, but it was a relatively easy, low-risk form of land use. The returns per hectare may also have been roughly similar to (semi-) subsistence agriculture. Ultimately, it was ranchers, able to accumulate on a larger scale than peasants, who were in a better position to dominate local land markets. While peasants bought and sold land amongst themselves, in ranching regions the long-term tendency was for ranchers to progressively consolidate peasant farms within their estates. And once incorporated, there was almost no going back.

\section{Agradecimientos}

Earlier versions of this chapter were presented at the Quinto Congreso Latino-Americano de Historia Económica (CLADHE V), in São Paulo, Brazil, July 19-21, 2016; and at the Seminar, "La historia de la ganadería en la costa caribe," in Cartagena, Colombia, Sept. 15, 2016. I particularly want to thank Jaime Torres Sánchez for his thoughtful comments.

\section{REFERENCES}

Ali, D. A. \& K. Deininger (2015). Is there a farm size-productivity relationship in African agriculture? Evidence from Rwanda. Land Economics, 91(2), 317-343.

Altieri, M. A., \& Toledo, V. M. (2011). The agroecological revolution in Latin America: Rescuing nature, ensuring food sovereignty and empowering peasants. Journal of Peasant Studies, 38(3), 587-612.

Archer, R. P. (1990). The transition from traditional to broker clientelism in Colombia: Political stability and social unrest (Working Paper, 140). Notre Dame, IN: The Helen Kellogg Institute for International Studies, University of Notre Dame.

Atkinson, L. J. (1970). Agricultural productivity in Colombia, Foreign Agricultural Economic Report, 66. U.S. Department of Agriculture.

Baines, S. \& Steen, D. R. (1971). Farm firm level analysis. Colombia agricultural sector analysis (Working Document Series No.17). U.S. Agency for International Development.

Balcázar, A. (1994). La ganadería en la Amazonia. ¿Instrumento de consolidación del colono? Coyuntura Colombiana, $11(1), 133-144$. 
Bardhan, P. K. (1973). Size, productivity, and returns to scale: An analysis of farm-level data in Indian agriculture. The Journal of Political Economy, 81(6), 1370-1386.

Barraclough, S. (1973). Agrarian structure in Latin America: A resumé of the CIDA land tenure studies of Argentina, Brazil, Chile, Colombia, Ecuador, Guatemala, Peru. Lexington, MA: Lexington Books.

Berry, A. \& Cline, W. R. (1979). Agrarian structure and productivity in developing countries. Baltimore: Johns Hopkins University Press.

Bhalla, S. S. \& Roy, P. (1988). Mis-specification in farm productivity analysis: The role of land quality”. Oxford Economic Papers (New Series), 40(1), 55-73.

Byres, T. (2004). Introduction: Contextualizing and interrogating the GKI case for redistributive land reform. Journal of Agrarian Change, 4(1-2), 1-16.

Caja de Crédito Agrario Industrial y Minero (1955). Producción nacional: Estudio sobre los principales aspectos del desarrollo de la producción agropecuaria. Bogotá: Caja de Crédito Agrario Industrial y Minero.

Caja de Crédito Agrario Industrial y Minero (1966). Informe de gerencia. (31 de diciembre de 1966). Bogotá: Caja de Crédito Agrario Industrial y Minero

Cespedes, L. (1979). Diagnóstico sobre la producción y mercadeo de maiz en Colombia (undergraduate thesis). Bogotá: Universidad Externado.

CIAT (1975). Cassava Production Systems. Cali: Centro Internacional de Agricultura Tropical.

CIDA (1966). Tenencia de la tierra y desarrollo socio-económico del sector agricola: Colombia. Washington, D.C.: Organización de los Estados Americanos.

Cornia, G. A. (1985). Farm size, land yields and the agricultural production function: An analysis for fifteen developing countries. World Development, 13(4), 513-534.

Crist, R. E. (1952). The Cauca Valley, Colombia: Land tenure and land use. Baltimore: The Waverly Press.

CVC (1962). Analisis económico de 109 fincas en el área del proyecto Roldanillo-La Unión-Toro, 1961-1962. Cali: Corporación Autónoma Regional del Cauca.

DANE (1964).Directorio nacional de exploitaciones agropecuario (censo agropecuario) 1960: Resúmen nacional. Bogotá: Departamento Administrativo Nacional de Estadística.

Dávila Tello, J. V. (1949). Economía agropecuario de Colombia, 1948. Bogotá: Ministerio de Agricultura y Ganadería.

Denevan, W. (1982). Causes of deforestation and forest and woodland degradation in tropical Latin America. Washington, D.C.: U.S. Congress, Office of Technology Assessment.

Dyer, G. (2004). Redistributive land reform: No April rose. The poverty of Berry and Cline and GKI on the inverse relationship. Journal of Agrarian Change, 4(1-2), 45-72.

Economic Commission for Latin America (1957). Analyses and projections of economic development III. The economic development of Colombia. Geneva: United Nations.

Fals Borda, O. (1976). Capitalismo, hacienda y poblamiento: Su desarrollo en la costa atlántica. Bogotá: Punta de Lanza.

Fals Borda, O. (2002). Historia doble de la costa (vols. 1-4). Bogotá: Universidad Nacional de Colombia, Banco de la República, and El Áncora Editores.

FEDEGAN (1971). La rentabilidad ganadera en el pais. Trabajo presentado a la VII Conferencia Consultiva de Ganaderos, Cúcuta, Mayo 27-29 de 1971. FEDEGAN.

Flórez, R. (1926).Fases de Colombia. Bogotá: Editorial Minerva.

Gaitán, G. (1984). La lucha por la tierra en la década del treinta: Génesis de la organización sindical campesina. Bogotá: El Áncora Editores.

Grajales, J. (2011). The rifle and the title: Paramilitary violence, land grab and land control in Colombia. Journal of Peasant Studies, 38(4), 771-792.

Griffin, E. (1973). Testing the von Thunen Theory in Uruguay. Geographical Review, 63(4), 500-516.

Griffin, K., Khan, A. R., \& Ickowitz, A. (2002). Poverty and the distribution of land. Journal of Agrarian Change, 2(3), 279-330. 
Shawn Van Ausdal. Pastures, crops, and inequality: Questioning the inverse relationship between f...

Griffin, K., Khan, A. R., \& Ickowitz, A. (2004). In defence of neo-classical neo-populism. Journal of Agrarian Change, 4(3), 361-386.

Grunig, J. E. (1968). Information, entrepreneurship, and economic development: A study of the decisionmaking process of Colombian latifundistas (doctoral dissertation). Madison: University of Wisconsin.

Grupo de Memória Histórica (Comisión Nacional de Reparación y Reconciliación) (2010). La tierra en disputa. Memorias de despojo y resistencia campesina en la costa Caribe (1960-2010). Bogotá: Taurus. 2010.

Guerra, G. E. (1966). Economic aspects for corn and milo in Colombia. Medellín: Universidad Nacional de Colombia, Facultad de Agronomía \& Instituto Forestal.

Haney, E. (1971). Possibilities for the economic reorganization of minifundia in a highland region of Colombia (Research Paper No. 43). Land Tenure Center, Madison: University of Wisconsin.

Havens, A. E., Montero, E., \& Romieux, M. (1965). Cereté: Un área de latifundio. Bogotá: Universidad Nacional de Colombia.

Hazell, P., Poulton, C., Wiggins, S., \& Dorward, A. (2010). The future of small farms: Trajectories and policy priorities. World Development, 38(10), 1349-1361.

Henderson, J. D. (1985). When Colombia bled: A history of the Violencia in Tolima. Tuscaloosa: University of Alabama Press.

Hirschman, A. O. (1963). Journeys toward progress; Studies of economic policymaking in Latin America. New York: Twentieth Century Fund.

Humphries, S. (1998). Milk cows, migrants, and land markets: Unraveling the complexities of forest-to-pasture conversion in northern Honduras. Economic Development and Cultural Change, 47(1), 95-124.

IBRD (1950). The basis of a development program for Colombia. Washington, D.C.: The International Bank for Reconstruction and Development.

ILMA (1964). Supply problems of basic agricultural products in Colombia. Bogotá: Instituto Latinoamericano de Mercadeo Agrícola.

Kalmanovitz, S. (1989). El régimen agrario durante el siglo XIX. In A. Tirado, J. Jaramillo \& J. O. Melo (Eds.), Nueva Historia de Colombia, vol. 2 .Era Republicana) (pp. 101-154). Bogotá: Planeta.

Kimhi, A. (2006). Plot size and maize productivity in Zambia: Is there an inverse relationship. Agricultural Economics, $35(1), 1-9$.

Lamb, R. (2003). Inverse productivity: Land quality, labor markets, and measurement error. Journal of Development Economics, 71(1), 71-95.

LeGrand, C. (1986). Frontier expansion and peasant protest in Colombia, 1850-1936. Albuquerque: University of New Mexico Press.

Londoño, D. R. (1975). Economic analysis of subsistence agriculture in Garcia Rovira, Colombia (doctoral dissertation). Stillwater: Oklahoma State University.

López, A. (1927). Problemas colombianos. Paris: Editorial París-América.

Martz, J. D. (1997). The politics of clientelism: Democracy and the state in Colombia. New Brunswick, NJ: Transaction Publishers.

Masterson, T. (2007). Productivity, technical efficiency, and farm size in Paraguayan agriculture (Working Paper No. 490). Annandale-On-Hudson, NY: The Levy Economics Institute, Bard College.

Molano, A. (1994). Algunas consideraciones sobre colonización y violencia. In A. Machado (Ed.), El agro y la cuestión social (pp. 27-41). Bogotá: Tercer Mundo Editores, Banco Ganadero, Caja Agraria, VECOL.

Molano, A. (1996). Selva adentro: Una historia oral de la colonización del Guaviare. Bogotá: El Áncora Editores.

Ocampo, G. I. (1988). Hacienda y campesinos en el Sinú. Formas de vida y formas de trabajo en 'Marta Magdalena' (1912-1954). Boletín Museo del Oro, 20, 112-129.

Ocampo, G. I. (2007). La instauración de la ganadería en el valle del Sinú. La hacienda Marta Magdalena, 1881-1956. Medellín: Editorial Universidad de Antioquia and Instituto Colombiano de Antropología e Historia. 
Oquist, P. (1980). Violence, Conflict, and Politics in Colombia. New York: Academic Press.

Palacios, M. (2011). ¿De quién es la tierra. Propiedad, politización y protesta campesina en la década de 1930. México: Fondo de Cultura Económica.

Posada Carbó, E. (1996). The Colombian Caribbean: A regional history, 1870-1950. Oxford: Clarendon Press.

Randell, C. G. (1953). La Industria Ganadera en Colombia. Washington, D.C.

Reyes, A. (1978). Latifundio y poder politico: La hacienda ganadera en Sucre. Bogotá: Editorial CINEP.

Reyes, A. (1986). Entrevista con James Parsons. Estudios Sociales (Medellín),1, 199-211.

Reyes, A. \& Duica, L. (2009). Guerreros y campesinos. El despojo de la tierra en Colombia. Bogotá: Norma.

Richards, A. (1979). The political economy of gutswirtschaft: A comparative analysis of East Elbian Germany, Egypt, and Chile. Comparative Studies in Society and History, 21(4), 483-518.

Schultz, T. (1964). Transforming traditional agriculture. New Haven: Yale University Press.

Shane, D. (1986). Hoofprints on the Forest. Philadelphia: Institute for the Study of Human Issues.

Smith, T. L. (1969). Agricultural-pastoral conflict: A major obstacle in the process of rural development. Journal of Inter-American Studies, 11(1), 16-43.

Taussig, M. (1974). Rural proletarianization; a social and historical enquiry into the commercialization of the southern Cauca Valley, Colombia (doctoral dissertation). London: The University of London.

Taussig, M. (1978). Peasant economics and the development of capitalist agriculture in the Cauca Valley, Colombia. Latin American Perspectives, 5(3) 62-91.

Thirsk, W. R. (1972). The economics of Colombian farm mechanization (doctoral dissertation). New Haven: Yale University.

Trant, G. I. (1958). Implications of calculated economic optima in the Cauca Valley, Colombia, S. A.Journal of Farm Economics, 40(1), 123-132.

Tucker, R. P. (2000). Insatiable Appetite: The United States and the Ecological Degradation of the Tropical World. Berkeley: University of California Press.

United Nations (1962). Livestock in Latin America; Status, Problems and Prospects. I. Colombia, Mexico, Uruguay and Venezuela. New York: United Nations.

United States Department of Commerce (1975). Historical statistics of the United States, colonial times to 1970. Washington, D.C.: U.S. Dept. of Commerce, Bureau of the Census.

Unal, F. G. (2008). Small is beautiful: Evidence of an inverse relationship between farm size and yield in Turkey (Working Paper No. 551). Annandale-On-Hudson, NY: The Levy Economics Institute, Bard College.

Van Ausdal, S. (2009a). Pasture, power, and profit: An environmental history of cattle ranching in Colombia, 1850-1950. Geoforum, 40(5), 707-719.

Van Ausdal, S. (2009b). The logic of livestock: An historical geography of cattle ranching in Colombia, 1850-1950 (doctoral dissertation). Berkeley: University of California.

Van Ausdal, S. (2012). Productivity gains and the limits of tropical ranching in Colombia, 1850-1950. Agricultural History, 86(3), 1-32.

Van Ausdal, S. (2016). Reimagining the tropical beef frontier and the nation in early twentieth century Colombia. In G. Winder and A. Dix (Eds.), Trading Environments: Frontiers, Commercial Knowledge and Environmental Transformation, 1820-1990 (pp. 166-192). London: Routledge.

Wiggins, S., Kirsten, J., \& Llambí, L. (2010). The future of small farms. World Development, 38(10), 1341-1348.

Wood, R. H., Jr. (1966). The base economy of Tolú (master's thesis). Madison: University of Wisconsin.

Wooten, H. H. (1953). Major uses ofland in the United States (Technical Bulletin No. 1082). Washington, D.C.: U.S. Department of Agriculture.

Wylie, K. (1942). The agriculture of Colombia (Foreign Agriculture Bulletin No. 1). Washington, D.C.: U.S. Department of Agriculture. 
Yepes, F. (2001). Ganadería y transformación de ecosistemas: un análisis ambiental de la política de apropiación territorial. In G. Palacio (Ed.), Naturaleza en disputa: ensayos de historia ambiental de Colombia, 1850-1995 (pp. 117-172). Bogotá: Universidad Nacional de Colombia, Instituto Colombiano de Antropología e Historia.

Zamosc, L. (1986). The agrarian question and the peasant movement in Colombia. Cambridge: Cambridge University Press.

Zapata Olivella, M. (1947). Tierra Mojada. Bogotá: Ediciones

\section{Notas}

1 The 1960 agricultural census identified 14.6 million hectares of permanent grasslands and pastures. The census did not include Intendencias (Arauca, Caquetá, Chocó, and La Guajira) or Comisarías (Amazonas, Putumayo, and Vaupés). The Economic Commission for Latin America (1957, p. 161) estimated that the Intendencias contained 1.7 million hectares of grasslands, while the Comisarías had an additional 5.3 million hectares, though these later were still relatively unimportant for the ranching industry. See also United Nations (1962, p. 14).

2 Peasants also raised cattle, more than is often realized. Yet in 1960 their territorial footprint paled in comparison to cattle estates: farms under 20 hectares ( $86 \%$ of total farms) controlled just 15 percent of the farmland, while ranchers monopolized about 80 percent of the farmland over 100 hectares (DANE, 1964, my calculations).

3 I am grateful to one of the anonymous reviewers for this suggestion.

4 Some of the texts consulted for this survey include: Ali \& Deininger, 2015; Berry \& Cline, 1979; Cornia, 1985; Griffin, Khan, \& Ickowitz, 2002; Griffin, Khan, \& Ickowitz, 2004; Hazell, Poulton, Wiggins, \& Dorward, 2010; Wiggins, Kirsten, \& Llambí, 2010; Kimhi, 2006; Unal, 2008; Masterson, 2007. The question of whether the IR exists, or how widespread it is, is the subject of considerable debate. For qualifications from within the field of economics, see Bhalla \& Roy (1988) and Lamb (2003). For a critique from a political economy perspective, see the special issue of the Journal of Agrarian Change edited by Terence Byres (2004).

5 According to the IR literature, these differences also occurred between different sized peasant farms

6 See Van Ausdal (2009a) for a critique of this perspective.

7 Marco A. Salazar to César Salazar, March 12, 1913, Libro de correspondencia, vol. 160 (1912-13), Archivo Pedro Nel Ospina y Compañía (APNOyC), Fundación Antioqueño de Estudios Sociales (FAES). This archive has since moved to the Universidad EAFIT in Medellín.

8 Marco A. Salazar to Juan de Dios Villa, June 16, 1916, Libro de correspondencia, vol. 210 (1916-17), APNOyC, FAES.

9 In these exchanges, a rancher would typically allow a peasant to farm a forested or similarly unproductive piece of his estate for several years in exchange for returning the land planted in pasture.

10 Taussig dismissed land sales because he considered peasant agriculture to be more productive than commercial farming. He did not, however, offer a good explanation for the "intriguing fact" that peasants "seem incapable of climbing out of debt" while commercial farms "make large profits and are constantly expanding" (Taussig, 1974, pp. 263, 270).

11 Comisión Investigadora to Juez Municipal \& Personero (Ayapel), May 30, 1925, Libro de correspondencia, vol. Varios (1925), APNOyC, FAES.

12 Comisión Investigadora to Juez Municipal \& Personero (Ayapel), May 30, 1925, Libro de correspondencia, vol. Varios (1925), APNOyC, FAES.

13 Comisión Investigadora to Juez Municipal \& Personero (Ayapel), May 30, 1925, Libro de correspondencia, vol. Varios (1925), APNOyC, FAES.

14 Bernardo Ospina to Pedro Nel Ospina, May 26, 1923, ff182-3, Libro de correspondencia, vol. Haciendas Cáceres (1923-24), APNOyC, FAES.

15 Bernardo Ospina to Pedro Nel Ospina, May 26, 1923, ff182-3, Libro de correspondencia, vol. Haciendas Cáceres (1923-24), APNOyC, FAES.

16 Often ranchers were able to take advantage of the precariousness of many peasant families in which crop failures, mounting debts, or sickness could precipitate the sale of land. For a fictionalized account of such pressures, see Zapata Olivella (1947).

17 ECLA (1957, p. 403) estimated that ranchers used, on average, one person per 50 head of cattle. This could be a function of the fact that most ranches, at least in the Caribbean region, had less than 100 head (Wylie, 1942,p. 119).

18 Memorandum of the farms of Caceres property of Pedro Nel Ospina \& Company, Feb. 1, 1922, Correspondencia enviada, vol. 1917-1936, APNOyC.

19 In one detailed study of a diversified cattle farm in Cereté, Havens, Montero, and Romieux (1965, pp. 222-234) found that the livestock component, which included dairy, earned more per hectare than (predominantly corn) farming. In 
1971, the national ranching association, FEDEGAN, undertook a nationwide, productivity study. Unfortunately, it only compares the relative productivity of different ranching regions in Colombia.

20 I excluded from this average both the higher estimates from departments where mechanized production was beginning to take hold and raise average yields (Valle, Córdoba, and Cundinamarca), and lower ones from the departments of Nariño and Magdalena.

21 For instance, during World War II, the US government tried to encourage landed elites from the Caribbean coast to grow rice for export to the Canal Zone. None were interested, the US consul reported, because the profits they earned from ranching were sufficient, especially compared to the increased risks and work of growing rice.

22 Berry \& Cline (1979, pp. 56-57) present similar results for Brazil. See also Ali \& Deininger (2015).

23 These limits were one reason why peasants also developed pastures where they could raise animals. These animals served both as a way to invest savings and to increase their overall production without substantially raising family labor demands.

24 Levy to Nelson Rockefeller, 5 April 1960, Folder 8/Box 1/Series A/Record Group 4 (Nelson A. Rockefeller), Rockefeller Family Archives, Rockefeller Archives (Sleepy Hollow, NY).

\section{BY-NC-SA}

